\title{
Description of two new species of Stenomicra Coquillett (Diptera, Periscelididae) from the Neotropics
}

\author{
Geovânia Freitas ${ }^{1,2} \&$ Rosaly Ale-Rocha ${ }^{1,2}$
}

\author{
'Instituto Nacional de Pesquisas da Amazônia (INPA), Coordenação de Pesquisas em Entomologia, CP 478, 69011-970 Manaus-AM, Brasil. \\ geovaniafreitas@bol.com.br; alerocha@inpa.gov.br \\ ${ }^{2} \mathrm{CNPq}$ fellowship
}

\begin{abstract}
Description of two new species of Stenomicra Coquillett (Diptera, Periscelididae) from the Neotropics. Two new Neotropical species of Stenomicra, S. (Stenomicra) amazonensis sp. nov. and S. (Stenomicra) manausensis sp. nov., are described. These are the first species of the genus reported from the Amazon region.
\end{abstract}

KEYWORDS. Brazil; South America; Stenomicrinae; taxonomy.

RESUMO. Descrição de duas espécies novas de Stenomicra Coquillett (Diptera, Periscelididae) da região Neotropical. Duas novas espécies neotropicais de Stenomicra, S. (Stenomicra) amazonensis sp. nov. e S. (Stenomicra) manausensis sp. nov., são descritas. Estas são as primeiras espécies do gênero encontradas na Região Amazônica.

PALAVRAS-CHAVE. América do Sul; Brasil; Stenomicrinae; taxonomia.

The genus Stenomicra Coquillett, 1900, type species $S$. angustata, was originally assigned to the family Drosophilidae (Coquillett 1900). The family placement of the genus has been controversial since that time. It was later transferred to Geomyzidae (Opomyzidae) (Sturtevant 1921), Asteiidae (Malloch 1927), Anthomyzidae (Collin 1944; Sabrosky 1965) and Aulacigastridae (Hennig 1971; Sabrosky 1975; Teskey 1987, among others), and also treated as a separate family, Stenomicridae (e.g., Papp 1984, 2001; Khoo \& Sabrosky 1989). The group has frequently received the status of subfamily (Grimaldi \& Mathis 1993; Mathis \& Papp 1998; Freiberg \& Mathis 2002). McAlpine (1978) removed the genus to Periscelididae, the classification followed herein. The division of Stenomicra into two subgenera, Stenomicra s. str. and Podocera Czerny, was proposed by Sabrosky (1975) and has been followed by subsequent authors (e.g., Freiberg \& Mathis 2002; Papp 1984; Khoo \& Sabrosky 1989; Merz \& Rohácek 2005).

Stenomicra is known from all biogeographical regions, with 34 extant species described (Grimaldi 2009), and two fossil species known from the Dominican Republic (Grimaldi $\&$ Mathis 1993). Four species are recorded from the Neotropics: S. angustata Coquillett from Puerto Rico, and three species from Costa Rica, S. flavida Hennig, S. parataeniata Hennig and S. taeniata Hennig (Coquillett 1900; Hennig 1956). More than 100 species are expected for the Neotropical region (Mathis \& Rung 2010).

According to Grimaldi (2009), Stenomicra, Cyamops and Stenocyamops are closely related genera, based on the following synapomorphies: lower portion of the face protruded, with projecting pair of "pseudovibrissae", ocellar and postocellar/ postvertical setae lost, postpronotal setae greatly reduced or absent, vein $\mathrm{Cu} \mathrm{A}_{1}$ with an abrupt distal end, tergite 7 and sternite 8 fused in males, females with syntergosternite 7 . Stenomicra includes slender specimens, which are usually lightcolored with narrow wings, and are distinguished from Cyamops and/or Stenocyamops by the maxillary palpus reduced to a small papilla; inner vertical proclinate; acrostichal setulae in one incomplete row or absent; anal lobe, alula and vein $\mathrm{A}_{1}+\mathrm{CuA}_{2}$ partially or virtually lost; anepisternum without silver microtomentum or setae on posterior margin; paired structures of the male genitalia symmetrical; and asymmetrical hypandrium (Grimaldi 2009).

Little is known about the biology of Stenomicra. Merz \& Rohácek (2005) reviewed the knowledge of the biology of this genus and suggested that most species may be associated with grass-like monocotyledons in wetland habitats, and may be phytophagous or saprophagous. Campos et al. (2010) provided information on the biological cycle of Stenomicra species in the Eryngium L. (Apiaceae).

A considerable quantity of specimens of Stenomicra from the Amazon region was collected and stored in the Invertebrate Collection of the Instituto Nacional de Pesquisas da Amazônia (INPA), Brazil, in recent years. The identification of the material revealed two undescribed species. These new species fit the definition of the subgenus Stenomicra according to Merz \& Rohácek (2005), and are described below. They are the first species of Stenomicra reported from the Amazon region.

\section{MATERIAL AND METHODS}

The material is housed in the Invertebrate Collection of the Instituto Nacional de Pesquisas da Amazônia (INPA). 
Most of the material was preserved in ethanol. These specimens were treated with ethyl acetate, then dried on tissue paper and mounted on triangles of resistant paper.

For the study of male and female terminalia, the abdomen was cut at the base of the first segment. Genital parts were cleared in hot $85 \%$ lactic acid, and then transferred to depression slides containing glycerin, for observation and illustration of structures. Subsequently the parts were wrapped in plastic microvials containing glycerin and attached to the corresponding pin specimen. The terminology of adult external morphology used herein follows Cumming $\&$ Wood (2009). The measurements follow the recommendations of Grimaldi (2009): W/L - greatest wing width to wing length as measured from cross vein $h$ to the wing tip; $\mathrm{L}$ $\mathrm{r}-\mathrm{m} / \mathrm{L}$ between $\mathrm{r}-\mathrm{m}$ and $\mathrm{m}-\mathrm{cu}-$ the ratio of length of cross vein $r-m$ to the length of the distance between this cross vein and $\mathrm{m}-\mathrm{cu}$; $\mathrm{ThL}$ - thorax length.

This material was collected mainly with "Suspensa" traps (Rafael \& Gorayeb 1982) installed in forest reserves near Manaus, state of Amazonas, Brazil. These traps were installed $1.5 \mathrm{~m}$ above the forest floor and in the canopy, along trails. The traps had yellow septa, and this color proved highly attractive to species of this genus. In the "Material" the data labels present a sequence of letters that refer to the position of the traps: the first letter or group of letters refers to the trail (AB, R, J, C, EE, LL), the second refers to the position of the trap in relation to the forest edge $(\mathrm{I}=$ interior; $\mathrm{B}=$ border $)$, and the third letter or group of letters refers to the height at which the trap was installed above the forest floor $(\mathrm{SB}=$ at $1.5 \mathrm{~m}$ above the forest floor; $\mathrm{D}=$ canopy). Label data of types are cited in full, with original spelling, punctuation and date.

\section{Stenomicra Coquillett}

Stenomicra Coquillett, 1900: 262. Type species: S. angustata Coquillett, by original designation. Sabrosky 1965: 820 [Nearctic catalog], 1980: 648-649 [Afrotropical catalog]; Papp 1984: 62 [Palaearctic catalog]; Khoo \& Sabrosky 1989: 551 [Australasian/Oceanian catalog]; Merz \& Rohácek 2005: 519-539 [review and key to species of western Palaearctic]; Grimaldi 2009 [Fiji species].

Podocera Czerny, 1929: 93. Type species: P. ramifera Czerny, by monotypy. Neoscaptomyza Séguy, 1938: 347. Type species N. bicolor Séguy, by original designation.

Diadelops Collin, 1944: 265. Type species: D. delicatus Collin, by monotypy.

Diagnosis. Cosmopolitan small flies, usually light in color, with narrow wings and maxillary palpus reduced; inner vertical bristle present and proclinate; ocellar and postocellar/ postvertical bristles absent; lower portion of the face protracted, with a pair of "pseudovibrissae"; acrostichal setulae in one incomplete row, or absent; anepisternum without silver microtomentum or setae on posterior margin; postpronotal setae greatly reduced to absent; anal lobe, alula and vein $\mathrm{A}_{1}+$ $\mathrm{CuA}_{2}$ partially or completely lost; $\mathrm{CuA}$, vein with an abrupt end; abdomen slender; tergites $7+8$ fused in males, females with syntergosternite 7; paired structures of the male genitalia symmetrical; and asymmetrical hypandrium (Grimaldi 2009).

\section{Stenomicra (Stenomicra) amazonensis sp. nov.}

\author{
(Figs. 1-7, 15, 16)
}

Diagnosis. Species with large brown to black setae on head and thorax; ocellar tubercle located in the middle of the frons; pedicel dark yellow basally and brown dorsally; arista with 8 dorsal and 2 ventral branches; inner vertical seta almost as long as outer vertical seta; scutum brown with lateral yellow stripe extending from transverse suture to posterior margin; 2 dorsocentral setae long; 1 katepisternal seta; wing evenly dark with vertical hyaline stripe in basal, middle and distal regions; tergites brown except T1 and T4 yellow; legs yellow, except mid femur with brown anterodorsal surface, hind femur brown with yellow extremities, and basal halves of mid and hind tibiae brown.

Description. Holotype male. Body: $2.0 \mathrm{~mm}$. Wing: $2.0 \mathrm{~mm}$. ThL: 0.75. Head subtriangular in frontal view (Fig. 15). Eyes emarginated on face around antennae and on postgenal margin; with dense short interfacetal setulae and no differentiation of facets. Frons shiny yellow; ocellar tubercle dark brown, located in the middle of the frons. Face long, extended below margin of eyes for about $1 / 3$ of the length of the eyes, slightly concave between antennae and with angular facial protuberance on lower portion, shiny dark-yellow, brownish on facial protuberance and with a paler longitudinal median stripe from base of antenna to margin of eyes; pair of robust pseudovibrissae on facial protuberance plus two lower pairs of setae aligned vertically below, all lateroclinate; five slender bristles on each side of oral margin, decreasing gradually in length towards gena; distance between pseudovibrissae $1 / 3$ of the distance between margins of eyes on face. Postgena yellow with sparse yellow pruinescence and several short slender setae. Postocellar setae lacking. Antenna with scape and first flagellomere yellow, pedicel dark yellow basally and brown dorsally; scape very short; pedicel with dorsal seam and brown setae, one dorsoapical well developed seta, 2 dorsal and one lateral slender setae; first flagellomere subrectangular, with numerous thin setae on frontal edge; arista sub-basal dorsal, yellow, with 8 dorsal branches decreasing gradually in length towards apex of the arista and 2 long ventral branches. Mouthparts yellow. Postcranium yellow with sparse yellow pruinescence and short thin setae. Setae brown to black. Larger setae: 1 outer vertical reclinate as long as frons length; 1 inner vertical only slightly smaller than outer, proclinate; 2 frontoorbital reclinate, posterior pair twice longer than the anterior pair and as long as outer vertical pair. Thorax. Scutum brown with lateral yellow stripe from transverse suture to posterior margin of scutum; scutellum and subscutellum brown; pronotum, postpronotum and notopleuron yellow; pleurae brown except proepisternum and katepisternum yellowish; anepisternum with dense pale pruinescence; sternum yellow. Acrostichal and dorsocentral uniserial, with short fine setulae; acrostichal series with 6-7 setulae in an incomplete row. Anepisternum without setae; ventral surface of katepisternum and mesosternum with fine yellow setulae. Large setae: 2 

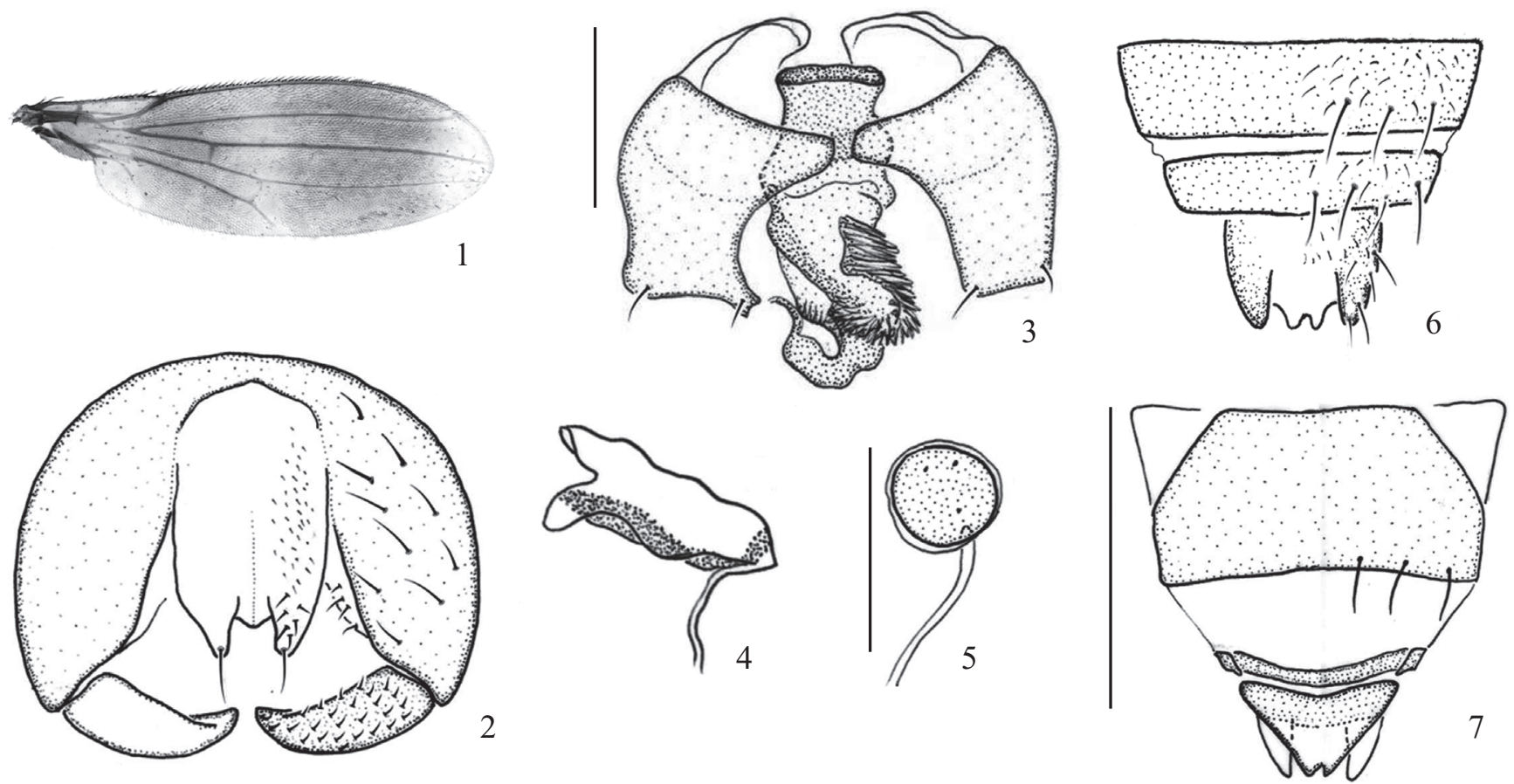

Figs. 1-7: Stenomicra amazonensis sp. nov. 1, wing. 2-4 male terminalia: 2, epandrial complex, posterior view; 3, hypandrium, phallus and aedeagal apodeme; 4, ejaculatory apodeme. 5-7, female terminalia: 5, spermatheca; 6 , terminalia, dorsal view; 7, terminalia, ventral view. Figs. $2-4$ in the same scale, scale bar $=0.1 \mathrm{~mm}$; fig. 5 , scale bar $=0.1 \mathrm{~mm}$; figs. 6,7 in the same scale, scale bar $=0.3 \mathrm{~mm}$.

dorsocentral pairs inserted at posterior half of scutum, posterior pair robust and as long as half the length of the scutum, anterior pair slender and about two-thirds the length of the posterior pair; 1 postpronotal; 1 supra-alar presutural; 2 notopleural as long as notopleuron length; 1 katepisternal; 1 scutellar apical as long as posterior dorsocentral setae. Legs yellow except mid femur with brown anterodorsal surface, hind femora brown with yellow extremities and basal halves of mid and hind tibiae brown, hind tarsi whitish-yellow. Ventral surface of coxae with fine yellow setulae; fore femur with posteroventral developed bristles; midtibia with ventral apical developed and robust black spur, ca. $2.5 \mathrm{x}$ apical width of tibia. Wing (Fig. 1) smoothly darkened with a hyaline vertical stripe in basal, middle and distal regions; $\mathrm{W} / \mathrm{L}=0.35$; $\mathrm{M} 1$ complete; $\mathrm{CuA}_{1}$ short, smaller than $1 / 4$ the length of $\mathrm{B}+\mathrm{D}$ cell; $\mathrm{CuA}_{2}$ incomplete; section $\mathrm{R}_{2+3}-\mathrm{R}_{4+5}$ about 3.5 times longer than section $\mathrm{R}_{4+5}-\mathrm{M}_{1} ; \mathrm{L} \mathrm{r}-\mathrm{m} / \mathrm{L}$ between $\mathrm{r}-\mathrm{m}$ and $\mathrm{m}-\mathrm{cu}=0.37$. Alula small, anal lobe present. Costa with stout setae at base and near apex of $\mathrm{R}_{1}$.

Abdomen. Tergites brown except T1 and T4 yellow; sternites pale yellow. Terminalia (Figs. 2, 3, 4): epandrium deep with strong and developed bristles pointed upward; inner apical walls (bacilliform sclerite) with few slender setae; cercus largely membranous, large, reaching the posterolateral margin of epandrium with small thin setulae and a more robust bristle at the apex of each lobe. Surstylus broad, slightly convex, with many minute stout setae pointed upward. Hypandrium divided in two chambers, semi-symmetrical. Aedeagus short and robust, with comb with spines and apex turned to left; phallapodeme broad. Ejaculatory apodeme as illustrated.

Female. As in male except for the face, which is brown, convex on lower portion but rounded, not angular as in the male (Fig. 16); eyes more widely spaced on face; and 3 setae on oral margin. Terminalia (Figs. 5, 6, 7): syntergosternite 7 longer ventrally than dorsally; sternite 8 reduced to a narrow strap; hypoproct triangular with distal margin split; cerci developed. Two spherical spermathecae with hyaline halo and sparse tiny and weakly pigmented granules.

Type material. Holotype male: BRAZIL. Amazonas, Manaus, Reserva Florestal Adolpho Ducke, Baixio, trilha Leste/Oeste, 21.vi.-06.vii.2007, Arm. Amarela, Freitas, G., Feitosa, M. (INPA). Condition of type: mounted on resistant paper triangle, in good condition, not dissected. Paratypes: BRASIL. Amazonas, Manaus, Res. km 41 PDBFF, 24-25.ii.2004, Trilha C I SB, Querino, 1 male; 12-13. v.2004,, 2 females, 3 males; 26-27.v.2004, SB, 5 females; 09-10.vi.2004, Dossel, 1 male; 09-10.vi.2004; 4 females; 23-24.vi.2004, sub-bosque, 2 females; 07-08.vii.2004, trilha EE I SB, 1 male; 07-08.vii.2004, trilha EE B SB, 1 male; 21-22.vii.2004, sub-bosque, 1 female; 05-06.viii.2004, B SB, 1 female; 18-19.viii.2004, EE I SB, 3 females; 01-02.ix.2004, trilha AB I SB, 2 females; 01-02.ix.2004, I SB, 2 females, 1 male; 15-16.ix.2004, J SB, 1 female; 18-19.ix.2004, trilha AB B SB, 1 female; 13-14.x.2004, trilha J B SB, 1 female; 13-14.x.2004, trilha R I SB, 2 females; 27-28.x.2004, trilha LL I SB, 2 females; 27-28.x.2004, trilha AB B SB, 1 female; 27-28.x.2004, trilha AB I SB, 1 female; 2728.x.2004, trilha EE I SB, 1 female; 27-28.x.2004, trilha R I SB, 1 female; 2.xii.-04-07.i.2005, trilha R I SB, 1 male; 19-21.i.2005, sub-bosque, 1 male; 02-04.iii.2005, sub-bosque, 3 males; 16-18.iii.2005, sub-bosque, 1 male; 30.iii-30.x.2005, sub-bosque, 2 males; Reserva F. Adolpho Ducke, Baixio, Trilha Norte/Sul, 26.xii.06-11.i.2007, Arm. Amarela, Sub-bosque, Feitosa, M.\& Freitas, G., 2 females; Platô Trilha Leste/Oeste, 14.ii a 06.iii.2007, 1 female, 1 male; Baixio Trilha Leste/Oeste, 4 females, 1 male; Platô Norte/ 
Sul, 17.iv-04.v.2007, Freitas, G \& Freitas, Silva, R.A., 3 females; Baixio trilha Leste/Oeste, 21.vi.-06.vii.2007, Freitas, G., Feitosa, M., 2 females, 3 males; Platô Norte/Sul, 03.viii-17.viii.2007, Barbosa, S.B., Freitas, G., Feitosa, M., 1 male.

\section{Distribution. Brazil (Manaus, Amazonas).}

Discussion. Stenomicra amazonensis sp. nov. can be distinguished from other Neotropical species of Stenomicra by the character set of the wing: length of the section $\mathrm{R}_{2+3}-\mathrm{R}_{4+5}$ 3.5 times longer than the length of the section $\mathrm{R}_{4+5}-\mathrm{M}_{1}$; wing darkened, with three hyaline vertical stripes. In addition, Stenomicra amazonensis $\mathbf{s p . ~ n o v . ~ c a n ~ b e ~ e a s i l y ~ d i s t i n g u i s h e d ~}$ from Stenomicra manausensis sp. nov. by the long and robust setae of the head and thorax, short $\mathrm{CuA}_{1}$, epandrium with elongated and robust bristles, cercus long, surstylus with short and spine-like bristles, and two epandrial lobes separated ventrally by a membranous area.

\section{Stenomicra (Stenomicra) manausensis sp. nov.}

(Figs. 8-14, 17)

Diagnosis. Species yellow except posterior margin of scutum, basal $2 / 3$ of scutellum and tergites 3,4 brown; bristles of head and thorax short, pale brown to yellow; ocellar tubercle located on vertex; post-gena with two short but conspicuous bristles; arista with 7 dorsal and 4 ventral long brown branches; outer vertical seta reclinate, two times longer than inner vertical seta; inner vertical minute; 1 dorsocentral pos- terior, 2 katepisternal, one small and one well developed; anepisternum with short thin setae; wing hyaline; legs yellow.

Description. Holotype male. Body: $1.68 \mathrm{~mm}$. Wing: 1.36 mm. ThL: 0.55. Head (Fig. 17) rounded. Eyes emarginated on face around antennae and on postgenal margin, with dense short interfacetal setulae and no differentiation of facets. Frons shiny yellow; dark brown ocellar tubercle located on vertex. Face short, about $1 / 7$ of the length of the eyes, slightly concave between antennae and with angular facial protuberance on lower portion, shiny yellow; setae short but stout, pair of pseudovibrissae inserted on facial protuberance slightly more robust than the remaining setae, plus two lower pairs aligned obliquely below, all lateroclinate; four downward-directed setae on each side of oral margin; distance between pseudovibrissae $1 / 3$ of the distance between margins of eyes on face. Postgena yellow with sparse yellow pruinescence and two short but distinct setae. Postocellar setae lacking. Antenna yellow; scape very short; pedicel with dorsal seam and few pale brown setae short, inconspicuous, one dorsoapical seta more developed than the others; first flagellomere ovate with sparse inconspicuous short setulae on frontal edge; sub-basal dorsal yellow arista with seven dorsal and four ventral branches, long and brown. Mouthparts yellow. Postcranium yellow with sparse yellow pruinescence and two short thin setae. Setae pale brown to yellow. Larger setae: 1 outer vertical proclinate about $1 / 3$ the length of the frons, two times longer than the inner vertical; 1 inner vertical minute, proclinate; 2 fronto-orbital reclinate, posterior pair twice longer than the anterior and as long
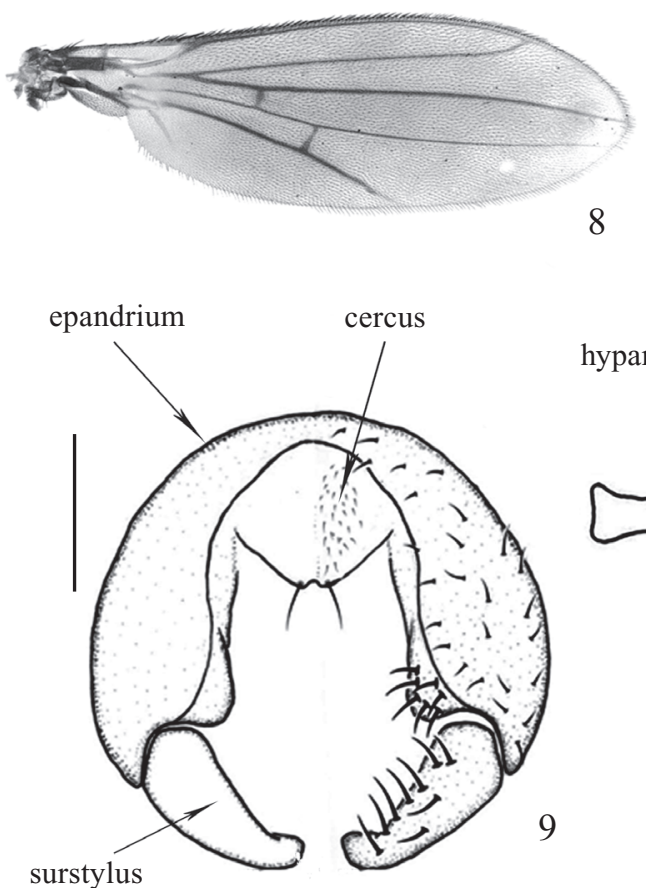
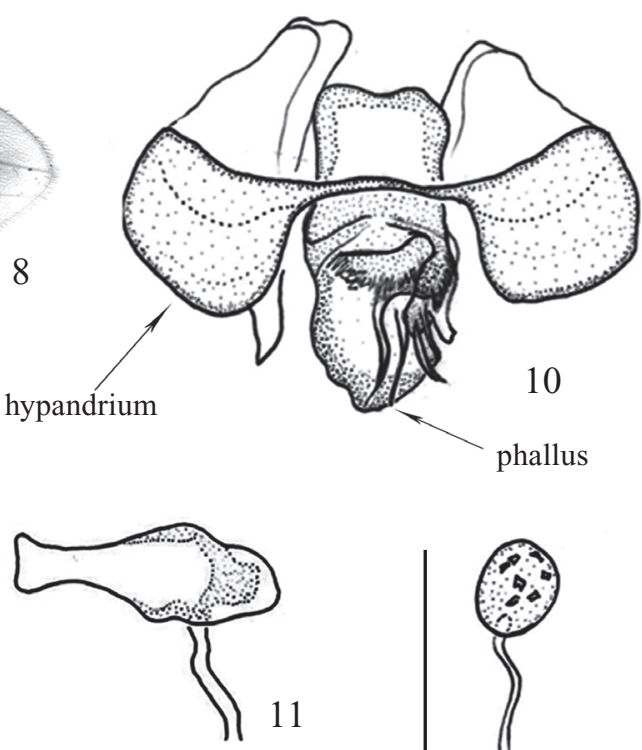
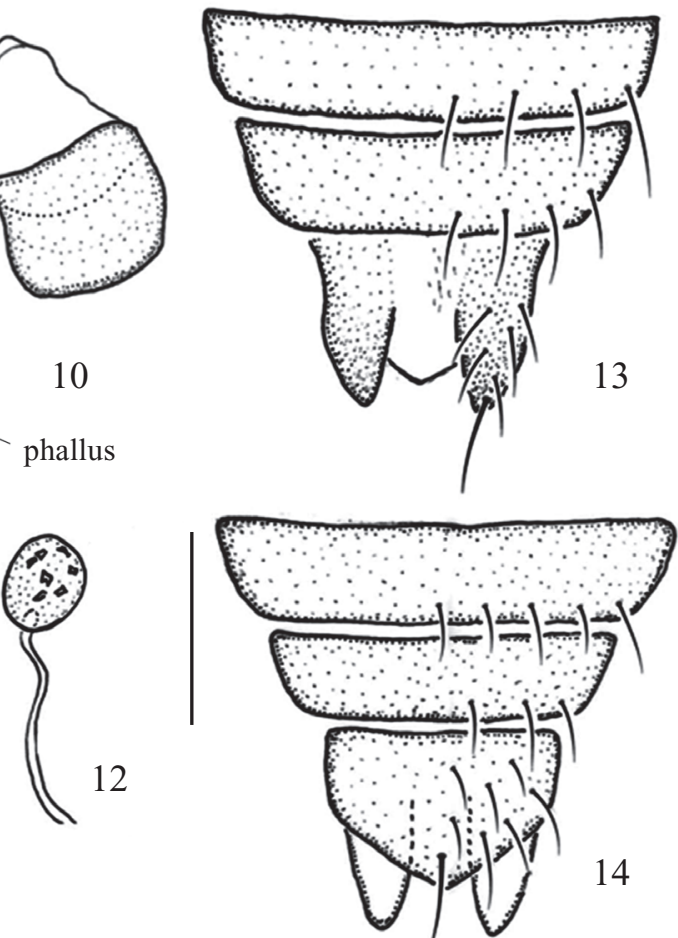

Figs. 8-14: Stenomicra manausensis sp. nov. 8, wing. 9-11, male terminalia: 9, epandrial complex, posterior view; 10, hypandrium, phallus and aedeagal apodeme; 11, ejaculatory apodeme. 12-14, female terminalia: 12, spermatheca; 13, terminalia, dorsal view; 14, terminalia, ventral view. Figs. 9-11; 6-7 in the same scale. Scale bar $=0.1 \mathrm{~mm}$. 

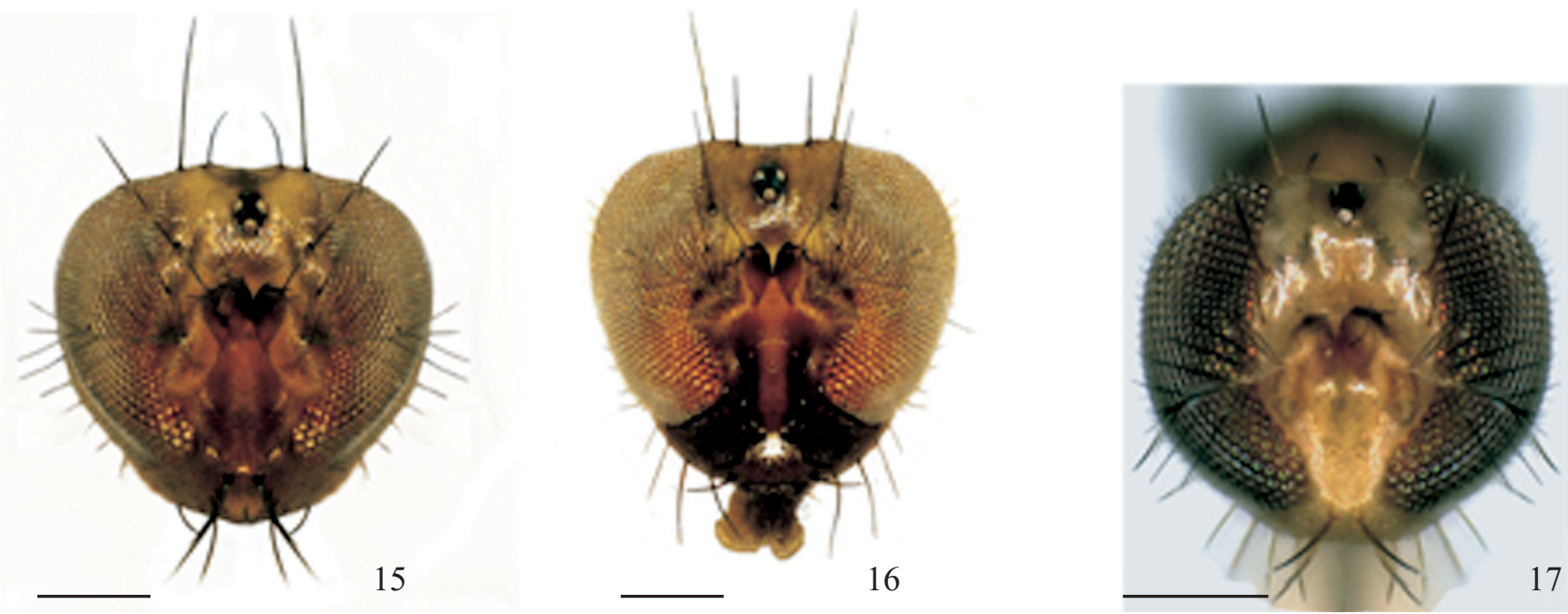

Figs. 15-17. Heads, anterior view: 1, Stenomicra amazonensis sp. nov., male; 2, Stenomicra amazonensis sp. nov., female; 3, Stenomicra manausensis sp. nov., male. Scale bar $=0.20 \mathrm{~mm}$.

as outer vertical seta. Thorax. Scutum shiny yellow with brown distal margin, sparse yellow-gold pruinescence; brown scutellum with distal margin yellow; subscutellum yellow; pronotum and postpronotum pale yellow; pleurae and sternum yellow. Setae short, fine, pale brown to yellow; acrostichals biserial, in complete rows; dorsocentral uniserial; anepisternum with 3 short fine setae on posterior upper margin, ventral surface of katepisternum and mesosternum with fine yellow setulae. Larger setae: 2 dorsocentral pairs inserted on posterior $1 / 5$ of scutum, anterior pair slender and about two-thirds length of posterior pair, posterior pair about $1 / 4$ length of scutum; 1 postpronotal; 1 supra-alar presutural, 2 notopleural; 2 katepisternal, one small and other well developed; 1 apical scutellar pair as long as posterior dorsocentral seta; anepisternum with short thin setae; ventral surface of katepisternum and mesosternum with fine yellow setulae. Legs yellow. Fore coxa with two conspicuous anterodorsal setae; fore femur with five posteroventral elongated bristles; hind femur with one large dorsal seta at distal third; midtibia with apical ventral developed yellow spur, ca. 2x apical width of tibia. Wing (Fig. 8) hyaline, $\mathrm{W} / \mathrm{L}=0.40 ; \mathrm{M}_{1}$ complete; $\mathrm{CuA}_{1}$ almost reaching apex of wing, elongate, about $1 / 2$ length of $\mathrm{D}+\mathrm{B}$ cell; $\mathrm{CuA}_{2}$ incomplete; section of $\mathrm{R}_{2+3}-\mathrm{R}_{4+5}$ almost 3.7 times longer than $\mathrm{R}_{4+5}+\mathrm{M}_{1}$; $\mathrm{L} \mathrm{r}-\mathrm{m} / \mathrm{L}$ between $\mathrm{r}-\mathrm{m}$ and $\mathrm{m}-\mathrm{cu}=0.33$. Alula small, anal lobe present. Costa with 2 stout setae at base and 1 spine-like seta at apex of R1. Abdomen. Tergites yellow except distal margin of tergite 2 and all of tergites 3 and 4 brown; sternites pale yellow. Terminalia (Figs. 9, 10, 11): epandrium deep, with short thin setae; inner apical walls (bacilliform sclerite) with many spine-like developed bristles near base of surstylus; cercus largely membranous, short, not reaching half height of epandrium, lobe reduced with small thin setulae and a long developed bristle at apex of each lobe. Surstylus broad and curved slightly inward, with many long spine-like bristles. Hypandrium semi symmetrical, with two chambers joined in the middle by a narrow bridge. Aedeagus short and robust, with long robust spicules; aedeagal apodeme broad. Ejaculatory apodeme as illustrated.

Female. As in the male. Terminalia (Figs. 12, 13, 14): syntergosternite 7 similar in length on dorsum and ventrally; sternite 8 as long as tergite 8 ; hypoproct heptagonal with apex on tip, and long stout setae. Two spherical spermathecae with coarse, heavily pigmented granules.

Type Material. Holotype male: BRAZIL, Amazonas, Manaus, Reserva Florestal Adolpho Ducke; Platô trilha Leste/Oeste; 21.vi-06.vii.2007, Arm. Suspensa Amarela, Sub-bosque, Freitas, G. \& Feitosa, M. Condition of type: mounted on resistant paper triangle, in good condition, not dissected. Paratypes: BRASIL, Amazonas, Manaus, Res. km 41 PDBFF, 12-13.v.2004, sub-bosque, R. Querino, 2 females, 1 male; 26-27.v.2004, 2 females, 1 male; 09-10.vi.2004, 2 females, 3 males; 09-10.vi.2004, Dossel, 2 females; 2324.vi.2004; Sub-bosque, 2 females; 07-08.vii. 2004; Trilha AB B SB, 1 females; Trilha EE I SB, 2 males; 21-22.vii.2004, Sub-bosque, 2 males, 1 female; 05-06.viii.2004, B SB, 2 females; C I SB, 1 female; 18-19.viii.2004, I SB, 2 males; B SB, 1 male; Trilha G I SB, 1 male; 15-16.ix.2004, B SB, 1 female; 29-30.ix.2004, Interior Dossel, 1 female, 1 male; Trilha EE I D, 4 males; I D, 2 males; 13-14.x.2004, trilha R I SB, 2 females; 15-16.x.2004, trilha R I SB, 1 female; 27-28.x.2004, trilha R I SB, 1 female; 27-29.x.2004, Trilha C I SB, 2 males; Trilha J I SB, 1 female, 1 male; Trilha LL I SB, 1 male; 10-12.xi.2004, J I SB, 1 male; Trilha AB B SB, 1 male; R B SB, 2 males; Trilha EE I SB, 1 female, 2 males; Trilha EE B SB, 1 male; trilha R I SB, 2 females; 24-25. xi. 2004, AB I SB, 3 males; Trilha J B SB, 1 female; Trilha AB B SB, 1 female; 08-09.xii.2004, Trilha R I SB, 1 female; Trilha EE I SB, 1 female, 1 male; Trilha LL B SB, 2 males; Trilha J I SB, 1 male; 19-21.i.2005, Sub-bosque, 1 female, 3 males; 02-04.ii.2005, Sub-bosque, 1 male; 16-17. ii.2005, Subbosque, 1 female, 1 male; 02-04.iii.2005, Sub-bosque, 4 females; 16-18.iii. 2005, Sub-bosque, 3 females, 5 males; 30.iii-30.x.2005, Sub-bosque, 7 females, 2 males; Reserva F. Adolpho Ducke, Platô trilha Leste/Oeste; 0106.ix.2006, Arm. Suspensa Amarela, Sub-bosque, Vidal. J., Ale-Rocha, R., Freitas, G., 1 female; Platô Trilha norte/Sul, 27.ix-09.x.2006, 1 male; 0920.x.2006, P. F. S. Augusto Rafael, 2 males; Baixio Trilha Leste/Oeste, 14.ii06.iii.2007, Freitas, G., Feitosa, M., 3 females, 3 males; Platô Trilha Norte/ Sul, 1 female, 2 males; 17.iv-04.v.2007, Freitas, G., Silva, R. A., 11 females, 5 males; Platô Trilha Leste/Oeste, 5 females, 4 males; Platô Trilha Leste/ Oeste, 21.v-06.vii.2007, Freitas, G., Feitosa, M., 5 females, 3 males; Baixio Trilha Leste/Oeste, 2 females, 2 males; Platô Trilha Norte/Sul, 03.viii17.viii.2007, Barbosa, S. B., Freitas, G., Feitosa, M., 1 female. 
Distribution. Brazil (Manaus, Amazonas).

Discussion. Stenomicra manausensis sp. nov. departs from the definition of Stenomicra by Grimaldi (2005) in having acrostichal setae arranged in two rows. This species can be distinguished from other Neotropical species of Stenomicra by the character set of the wing and body coloration: scutum yellow, distance from the section $\mathrm{R}_{2+3}-\mathrm{R}_{4+5} 3.5$ times longer than the distance from the section $\mathrm{R}_{4+5}-\mathrm{M}_{1}$ and the wing is hyaline. In addition, Stenomicra manausensis sp. nov. can be easily distinguished from Stenomicra amazonensis sp. nov. by the short setae on the head and thorax, the epandrium with short slender setae, cercus short, setae of surstylus long and robust, and hypandrium not divided.

\section{Key for Neotropical species of Stenomicra}

1. Section $R_{2+3}-R_{4+5} 3.5$ to 4 times larger than section $M_{1}-R_{4+5}$ 1 '. Section $\mathrm{R}_{2+3}-\mathrm{R}_{4+5}$ half length of, or same length as section $M_{1}-R_{4+5} \cdots \cdots$

2. Scutum entirely brown; wing hyaline (Puerto Rico) .......

Scutum and wing variable S. angustata Coquillett

3. Scutum yellow with posterior margin brown; abdomen yellow with distal margin of T2 and all of T3 and T4 brown; ocellar tubercle located on vertex (Fig. 17); wing hyaline (Fig. 8); hind leg yellow (Brazil) S. manausensis sp. nov.

3'. Scutum brown with lateral yellow stripe extending from transverse suture to posterior margin; abdomen brown except T1 and T4 yellow; ocellar tubercle located in the middle of the frons (Figs. 15, 16); wing dark, with hyaline vertical stripe at basal, middle and distal regions (Fig.1); mid and hind legs yellow except mid femur with brown anterodorsal surface, hind femur mostly brown and basal halves of mid and hind tibiae brown (Brazil)

S. amazonensis sp. nov.

4. Scutum black; wing brown with hyaline base; section $\mathrm{R}_{2+3}{ }^{-}$ $\mathrm{R}_{4+5}$ same length as section $\mathrm{M}_{1}-\mathrm{R}_{4+5}$ (Costa Rica) ............

S. taeniata Hennig

4'. Scutum predominantly yellow; wing hyaline; lengths of section $\mathrm{R}_{2+3}-\mathrm{R}_{4+5}$ and section $\mathrm{M}_{1}-\mathrm{R}_{4+5}$ variable .............. 5

5. Section $R_{2+3}-R_{4+5}$ half length of section $M_{1}-R_{4+5}($ Costa Rica) S. parataeniata Hennig

5'. Section $R_{2+3}-R_{4+5}$ of same length as section $M_{1}-R_{4+5}($ Costa Rica) S. flavida Hennig

\section{ACKNOWLEDGEMENTS}

We thank the Brazilian agency CNPq for the support of our project "Systematics of Periscelididae (Insecta, Diptera, Schizophora) from the Neotropical region, with emphasis on Amazonian species, process number 574999/2008-6, Edital CT Amazônia and the fellowship granted to the authors. We thank Dr. Ranyse Querino (EMBRAPA-RR) for collecting much of the material that formed the basis of this study.

\section{REFERENCES}

Campos, R. E.; M. C. Gramajo \& M. Lizarralde de Grosso. 2010. Stenomicra (Diptera: Opomyzoidea) in Argentina, with information on the biology of the genus. Revista de la Sociedad Entomológica Argentina 69 (34): 281-285

Collin, J. E. 1944. The British species of Anthomyzidae (Diptera). Entomologist's Monthly Magazine 80: 265-272.

Coquillet, D. W. 1900. Report on a collection of dipterous insects. Puerto Rico. Proceedings of the United States National Museum 22: 249 270.

Cumming, J. M. \& D. M. Wood. 2009. Adult morphology and terminology. p. 9-50. In: Brown, B.V.; Borkent, A.; Cumming, J. M.; Wood, D. M.; Woodley, N. E. \& Zumbado, M. A. (Eds.). Manual of Central American Diptera. Vol. 1. Ottawa, NRC Research Press, xi+714 p.

Czerny, L. 1929. Podocera ramifera, eine neue Gattung und Art der Perisceliden von Ceylon. Konowia 8: 93-94.

Freiberg, A. \& W. N. Mathis. 2002. The Periscelididae (Diptera) of Israel, with description of a new species of Stenomicra Coquillett. Israel Journal of Zoology 48: 43-51.

Grimaldi, D. A. 2009. The Asteioinea of Fiji (Insecta: Diptera: Periscelididae, Asteiidae, Xenasteiidae). American Museum Novitates 3671: 1-59.

Grimaldi, D. A. \& W. N. Mathis. 1993. Fossil Periscelididae (Diptera). Proceedings of the Entomological Society of Washington 95: 383-403.

Hennig, W. 1956. Neue neotropische Acalyptrata aus dem Deutschen Entomologischen Institut. Beiträge zur Entomologie 6: 146-154.

Hennig, W. 1971. Neue Untersuchungen über die Familien der Diptera Schizophora (Diptera: Cyclorrhapha). Stuttgarter Beiträge zur Naturkunde 226: 1-76.

Khoo, K. C. \& C.W. Sabrosky. 1989. Family Stenomicridae, p. 551. In: N. L. Evenhuis (Ed.). Catalog of the Diptera of the Australasian and Oceanian regions 86. Bishop Museum Special Publication, 1155 p.

Malloch, J. R. 1927. The species of the genus Stenomicra, Coquillet [sic] (Diptera, Acalyptrata). Annals and Magazine of Natural History (9) 20: $23-26$.

Mathis, W. N. \& L. Papp. 1998. Family Periscelididae, p. 285-294. In: L. Papp \& B. Darvas (Eds.), Contributions to a Manual of Palaeartic Diptera. Vol. 3. Science Herald, Budapest, 880 p.

Mathis, W. N. \& A. Rung, 2010. Periscelididae, p. 9-50. In: B. V. Brown; A. Borkent; J. M. Cumming; D. M. Wood; N. E. Woodley \& M. A. Zumbado (Eds.). Manual of Central American Diptera. Vol. 2, Ottawa, NRC Research Press, xv +1442 p.

McAlpine, D. K. 1978. Description and biology of a new genus of flies related to Anthoclusia and representing a new family (Diptera, Schizophora, Neurochaetidae). Annals of the Natal Museum 23: 273-295.

Merz, B. \& J. Rohácek. 2005. The Western Palaearct species of Stenomicra Coquillett (Diptera, Periscelididae, Stenomicrinae), with description of a new species of the subgenus Podocera Czerny. Revue Suisse de Zoologie 112: 519-539.

Papp, L. 1984. Family Stenomicridae, p. 61-63. In: A. Soós \& L. Papp (Eds.). Catalogue of the Palaearctic Diptera. Vol.10, Akadémiai Kiado, Budapest, 402 p.

Papp, L. 2001. Stenomicridae. p. 344-345. In: Checklist of the Diptera of Hungary. Budapest, Hungarian Natural History Museum, 550 p.

Rafael, J. A. \& I. N. Gorayeb. 1982. Tabanidae (Diptera) da Amazônia, I Uma nova armadilha suspensa e primeiros registros de mutucas de copas de árvores. Acta Amazonica 12: 232-236.

Sabrosky, C. W. 1965. Family Periscelididae, p. 710. In: A. Stone; C. W. Sabrosky; W.W. Wirth; R. H. Foote \& J. R. Coulson (Eds.). A catalog of the Diptera of America north of Mexico. Washington, D.C., USDA handbook 276, 1696 p.

Sabrosky, C.W. 1975. The genus Stenomicra in the Ethiopian Region (Diptera, Aulacigastridae). Annals of the Natal Museum 22: 663-676.

Sabrosky, C.W. 1980. 66. Family Aulacigastridae, p. 648-649. In: R. W. Crosskey (Ed.). Catalogue of the Diptera of the Afrotropical Region. London, British Museum (Natural History), v+1437 p. 
Séguy, E. 1938. Diptera. I. Nematocera et Brachycera. Mission Scientifique de L'Omo,Tome IV, Fascicule 39. Mémoires Muséum National d'Histoire Naturelle Paris (Novovelle Série) Série A (Zoologie) 8: 319-380.

Sturtevant. A. H. 1921. The North American species of Drosophila.
Carnegie Institution of Washington Publications 301: 1-150.

Teskey, H. J. 1987. 76. Aulacigastridae, p. 891-894. In: J. F. McAlpine; B.V. Peterson; G. B. Shewell; H. J. Teskey; J. R. Vockeroth \& D. M. Wood (Eds.). Manual of Nearctic Diptera. vol. 2. Reserarch Branch, Agriculture Canada, Monograph 28, 1332 p.

Received 10/4/2011; accepted 15/8/2011

Editor: Marcia Souto Couri 